\title{
Detection of viruses in the exotic shrimp Penaeus vannamei Boone, 1931 cultured in India
}

\author{
Y. MOGER RAJEISH, G. NARASIMHA MURTHY, HOOVINAHALLI NATARAJU MADHUSHREE \\ BASAVAREDDY R. PUJAR, SHIVANI KALLAPPA GIRISHA, T. SURESH AND \\ MOLEYUR NAGARAJAPPA VENUGOPAL \\ Department of Fisheries Microbiology, Karnataka Veterinary, Animal and Fisheries Sciences, University \\ College of Fisheries, Mangalore - 575 002, India \\ e-mail:mnvenu@rediffmail.com
}

\begin{abstract}
Pacific white shrimp Penaeus vannamei Boone, 1931, is a recently introduced species in India. P. vannamei samples, collected from various shrimp farms of Karnataka, India were subjected to polymerase chain reaction (PCR) based detection of whitespot syndrome virus (WSSV), hepatopancreatic parvovirus (HPV), monodon baculovirus (MBV), infectious hypodermal and hematopoietic necrosis virus (IHHNV), taura syndrome virus (TSV) and infectious myonecrosis virus (IMNV). Out of the 81 shrimp samples analysed, 41 samples $(50.6 \%)$ were found positive for WSSV and four $(4.9 \%)$ were positive for IHHNV. Among $41 \mathrm{WSSV}$ positive samples, $20(48.7 \%)$ samples were found positive for WSSV by $1^{\text {st }}$ step PCR, while the remaining 21 (51.2\%) samples were positive by nested PCR. WSSV positive samples were further confirmed by dot blot hybridisation assay. However, clinical signs/disease symptoms were not observed in any of the shrimp samples tested positive for the viruses.
\end{abstract}

Keywords: Aquaculture, Dot-blot hybridization, IHHNV, Penaeus vannamei, SPF shrimp, WSSV

\section{Introduction}

Aquaculture has been in practice for centuries in small rural settings but during the past few decades it has developed into a commercial activity worldwide. (Walker and Winton, 2010). Shrimp culture has become the major aquaculture activity in many developing countries to earn foreign exchange by exporting to developed countries, including United States of America, European Union and Japan (Bondad-Reantaso et al., 2005). Asia dominated the world in the production of cultured shrimp, mainly through the culture of black tiger shrimp, Penaeus monodon for a long time. However, its dominance has been successfully replaced by the introduction of the Pacific white shrimp, Penaeus vannamei, in many shrimp producing countries (Flegel, 2006b). The preference for $P$. vannamei over $P$. monodon is due to its rapid growth rate, tolerance to high stocking density, tolerance to low salinity and temperature, relatively low protein requirement, high survival rate during larval rearing and good marketability (Wayban et al., 1995; Briggs et al., 2004). Large scale use of specific pathogen free (SPF) $P$. vannamei has led to the highest production of cultivated shrimp in Asia (Flegel, 2006a).

Shrimp production in India which was mainly dependent on $P$. monodon, declined drastically to 75,997 $\mathrm{t}$ in 2008 , from a relatively high export production of 1,25,668 $\mathrm{t}$ in 2004 (MPEDA, 2016). This sharp decline was mainly attributed to exclusive culture of $P$. monodon and the associated disease problems. Lack of alternate species suitable for culture as well as the success associated with the culture of $P$. vannamei in neighboring countries prompted Indian shrimp industry to urge Government of India to permit the import of disease-resistant, SPF P. vannamei to India in 2009 (Remany et al., 2010). Consequent to the introduction of $P$. vannamei, the area under culture in India rapidly increased from 283 ha in 2009-10 to 50,240 ha in 200415 (MPEDA, 2016). However, the major concern was the possibility of introduction of pathogens along with exotic species (Tu et al., 1999; Phalitakul et al., 2006; Senanan et al., 2009). Though, P. vannamei is supposed to be resistant to viruses which mainly infect $P$. monodon, there are reports of viral disease problems associated with this species (Browdy et al., 1993; Lightner, 1999; Motte et al., 2002; Rodriguez et al., 2003; Mijangos-Alquisires et al., 2006; Afsharnasab et al., 2009; Dos Santos-Braz et al., 2009).

Since the culture of $P$. vannamei is rapidly expanding in India, it was felt necessary to investigate on the viruses associated with the species during culture operation. 
The present study investigated the presence of important shrimp viruses in P. vannamei cultured in the state of Karnataka, India.

\section{Materials and methods}

Sample collection

A total of 81 P. vannamei samples were collected from shrimp farms of Uttar Kannada and Udupi districts in Karnataka, India. The samples were immediately transported to the laboratory on ice and fixed in $95 \%$ ethanol.

\section{Detection of shrimp viruses}

The samples were checked for the presence of important DNA viruses such as WSSV, HPV, MBV, IHHNV and for the RNA viruses viz., TSV and IMNV which are considered pathogenic in shrimp aquaculture. The samples preserved in $95 \%$ ethanol, were rehydrated in distilled water for $1 \mathrm{~h}$ and viral DNA was extracted as per Otta et al. (2003). The shrimp DNA extracted from gills, pleopods and cuticle were used for detection of WSSV and IHHNV, while DNA from hepatopancreas was used for detection of MBV and HPV. Total RNA was extracted from gills, pleopods and muscle using $750 \mu \mathrm{l}$ of TRI Reagent ${ }^{\circledR}$ (Invitrogen, USA) for the detection of important RNA viruses. After $5 \mathrm{~min}$ incubation with vigorous mixing, $200 \mu \mathrm{l}$ of chloroform was added and incubated for $10 \mathrm{~min}$ at room temperature, followed by centrifugation at $14,000 \mathrm{~g}$ for $10 \mathrm{~min}$ at $4^{\circ} \mathrm{C}$. The aqueous phase was transferred to a fresh tube and mixed with $500 \mu$ of $100 \%$ isopropanol and was precipitated by centrifugation at $14,000 \mathrm{~g}$ for $10 \mathrm{~min}$ at $4^{\circ} \mathrm{C}$. The resultant RNA pellet was washed by adding $70 \%(\mathrm{v} / \mathrm{v})$ ethanol, air dried and finally suspended in $50 \mu \mathrm{l}$ of RNase-free water. The first strand cDNA was synthesised as per manufacturer's protocol (Invitrogen, USA) using virus specific reverse primers.

\section{PCR analysis}

The presence of DNA viruses such as WSSV, MBV, HPV and IHHNV were tested by one-step PCR and nested PCR. For the detection of RNA viruses, TSV and IMNV, OIE recommended protocols were followed (Nunan et al., 1998; Poulos and Lightner, 2006; OIE, 2010). The primer sequences as well as PCR protocol used for the detection of both DNA and RNA viruses and resultant amplicon sizes are detailed in Table 1.

The PCR reactions were performed in $30 \mu 1$ reaction volume containing $1 \mathrm{X}$ PCR buffer, $5 \mathrm{pmol}$ of each primer, $50 \mu \mathrm{mol}$ of each dATP, dCTP, dGTP and dTTP, 0.9 units of Taq DNA polymerase (HiMedia, Mumbai), $2 \mu \mathrm{l}$ of nucleic acid extract and adjusted to a final volume of $30 \mu \mathrm{l}$ using ultrapure water. Amplification was executed in a thermalcycler (BioRad, USA). PCR products were

Table 1. Primer sequences and PCR protocols used for the detection of shrimp viruses

\begin{tabular}{|c|c|c|c|c|}
\hline Virus & Primer name & Primer sequence $\left(5^{\prime}-3^{\prime}\right)$ & Product size (bp) & Reference \\
\hline \multirow[t]{4}{*}{ WSSV } & IK1 & TGGCATGACAACGGCAGGAG & 486 & Hossain et al. (2001) \\
\hline & IK2 & GGCTTCTGAGATGAGGACGG & & \\
\hline & IK3 & TGTCATCGCCAGCACGTGTGC & 310 & \\
\hline & IK4 & AGAGGTCGTCAGAGCCTAGTC & & \\
\hline \multirow[t]{4}{*}{ HPV } & $\mathrm{H} 441 \mathrm{~F}$ & GCATTACAAGAGCCAAGCAG & 441 & Phromjai et al. (2002) \\
\hline & H441R & ACACTCAGCCTCTACCTTGT & & \\
\hline & HPVnF & ATAGAACGCATAGAAAACGCT & 265 & Umesha et al. (2006) \\
\hline & HPVnR & CAGCGATTCATTCCAGCGCCACC & & \\
\hline \multirow[t]{4}{*}{ MBV } & MBV 1.4F & GCATTACAAGAGCCAAGCAG & 533 & Belcher and Young (1998) \\
\hline & MBV $1.4 \mathrm{R}$ & ACACTCAGCCTCTACCTTGT & & \\
\hline & MBV1.4NF & ATAGAACGCATAGAAAACGCT & 361 & \\
\hline & MBV1.4NR & CAGCGATTCATTCCAGCGCCACC & & \\
\hline \multirow[t]{4}{*}{ IHHNV } & IHHNV648F & CGATTCCATATCGGCCGAATA & 648 & Rai et al. (2009) \\
\hline & IHHNV648R & TTGGCATGCACTCCCTGAGAT & & \\
\hline & IHHNV309F & TCCAATCGCGTCTGCGATACT & 309 & Tang et al. (2007) \\
\hline & IHHNV309R & CGCTAATGGGGCACAAGTCTC & & \\
\hline \multirow[t]{4}{*}{ IMNV } & $4587 \mathrm{~F}$ & CGACGCTGCTAACCATACAA & 328 & Poulos and Lightner (2006) \\
\hline & $4914 \mathrm{R}$ & ACTCGGCTGTTCGATCAAGT & & \\
\hline & $4725 \mathrm{NF}$ & GGCACATGCTCAGAGACA & 139 & \\
\hline & $4863 \mathrm{NR}$ & AGCGCTGAGTCCAGTCTTG & & \\
\hline \multirow[t]{2}{*}{ TSV } & $9992 \mathrm{~F}$ & AAGTAGACAGCCGCGCTT & 231 & Nunan et al. (1998) \\
\hline & $9195 \mathrm{R}$ & TCAATGAGAGCTTGGTCC & & \\
\hline
\end{tabular}


resolved by agarose gel electrophoresis containing ethidium bromide $\left(0.5 \mu \mathrm{g} \mathrm{ml}^{-1}\right)$ and visualised in a Geldoc system (BioRad, USA).

\section{Dot blot hybridisation}

The PCR product of $310 \mathrm{bp}$ amplified from the DNA extracted from WSSV infected $P$. monodon using primer pair IK 3-4 was purified using DNA clean up kit (Qiagen, Germany) before being used for digoxigenin (DIG) labelling. WSSV probe was prepared by DIG random primed DNA labeling using DIG-High Prime DNA Labeling and Detection Starter Kit I (Roche, Switzerland) following manufacturer's instructions. Each of the sample DNA was denatured by boiling for $10 \mathrm{~min}$ and immediately chilled on ice. Two microliters of the sample was blotted on to a nylon membrane (Biodyne B Membrane, Pall Life Science, USA) and the nucleic acid was fixed to the membrane by cross linking with UV-light (UVC 500, Hoefer, USA). DIG-labelled probes were used for hybridisation to membrane blotted nucleic acids according to standard methods. Signal colour was developed using anti-DIG conjugated with alkaline phosphatase (Roche, Germany) and NBT-BCIP substrate (Roche, Germany) as directed by the manufacturer. DNA extracted from gill tissue of healthy $P$. vanname $i$ was used as negative control.

\section{Results and discussion}

A total of 81 cultured $P$. vannamei samples, from Uttar Kannada and Udupi districts of Karnataka, India were subjected for the detection of DNA viruses like WSSV, HPV, MBV and IHHNV using both one step PCR and nested PCR whereas RNA viruses like TSV and IMNV using OIE recommended protocols. Out of the 81 samples, $45(55.6 \%)$ were found positive for selected viruses and in $36(44.4 \%)$ samples, the tested viruses were not detected.

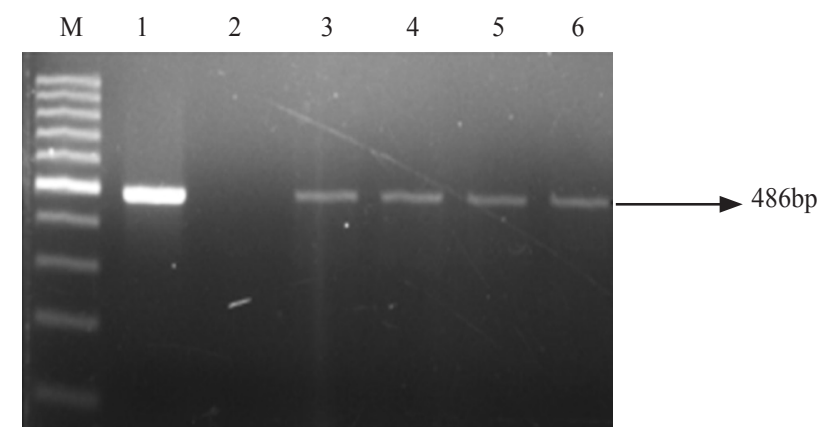

Fig. 1.PCR detection of WSSV in P. vannamei using WSSV specific primer sets IK1 and IK2

(1) M: 100 bp DNA ladder; (2) Lane 1: I ${ }^{\text {st }}$ step PCR amplification of positive control; (3) Lane 2: It step PCR amplification of negative control; (4) Lane 3 to 6: I'ststep PCR amplification of DNA extracted from $P$. vannamei
Incidence of WSSV in cultured $P$. vannamei is reported from Iran (Pazir et al., 2011), Taiwan (Cheng et al., 2013), Equador (Rodriguez et al., 2003) and Indonesia (Ferasyi et al., 2015). WSSV infection has caused mass mortalities of farmed $P$. vannamei, bringing huge loss to shrimp farmers around the world like Ecuador (Calderon et al., 1999), Brazil (Cavalli et al., 2008) and Iran (Afsharnasab et al., 2009). Likewise, many researchers have also reported $P$. vannamei mortality in farms due to WSSV alone or in combination with other pathogens from India (Balakrishnan et al., 2011; Otta et al., 2014; Sanathkumar et al., 2014). In another study from India, high prevalence $(72 \%)$ of WSSV in cultured $P$. vannamei samples has been reported (Moger et al., 2011). In our study, out of the 81 samples tested for WSSV by PCR, 41 samples $(50.6 \%)$ were found positive for the virus. Among the $41 \mathrm{WSSV}$ positive samples, 20 samples were found positive for WSSV by $1^{\text {st }}$ step PCR itself, suggesting high load of the virus (Fig. 1) and rest of the 21 samples were found positive by nested PCR by yielding PCR product size of 310 bp (Fig. 2). The shrimps detected positive for WSSV did not show any clinical signs of white spots. The results indicated that even though WSSV is present in the animal, this may not progress into disease unless the animal is stressed due to the deterioration of environmental parameters as observe by other workers (Tsai et al., 1999; Ananda Raja et al., 2012a,b). Similarly, Flegel et al. (2004) reported the presence of multiple viruses in non-diseased P. monodon.

Due to the high prevalence of WSSV in the samples, the presence of specific viral DNA was confirmed by subjecting it to dot-blot hybridisation. Dot-blot assays of DNA extracts from shrimp yielded positive results (Fig. 3) for WSSV that matched corresponding samples with positive bands for WSSV in PCR gel analysis. The

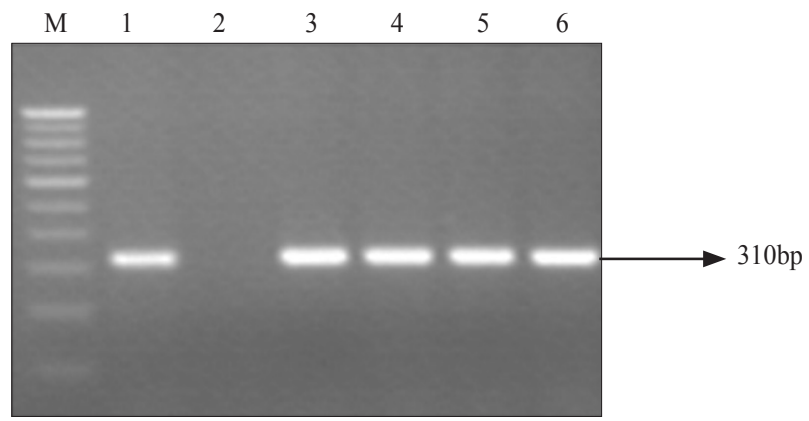

Fig. 2.Nested PCR detection of WSSV in P. vannamei using WSSV specific primer sets IK3 and IK4

(1) M: 100 bp DNA ladder; (2) Lane 1: Nested PCR amplification of positive control; (3) Lane 2: Nested PCR amplification of negative control; (4) Lane 3 to 6: Nested PCR amplification of DNA extracted from P. vannamei 


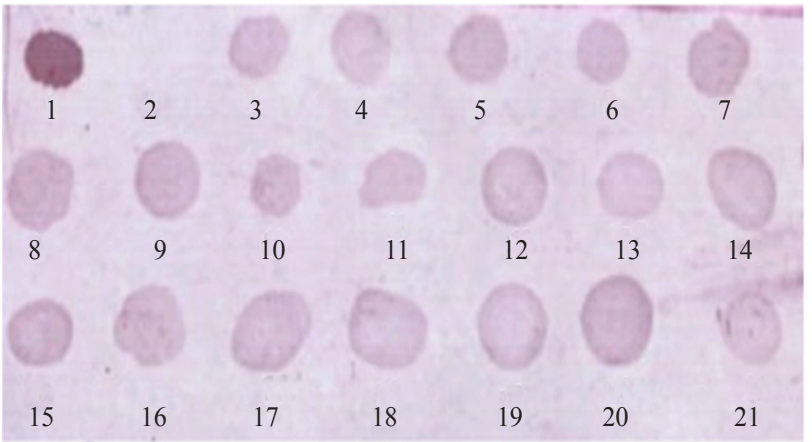

Fig. 3. Confirmation of WSSV infection of $P$. vannamei by dot-blot hybridisation

Spot 1: Positive control; Spot 2: Negative control; Spots 3-12: P. vannamei samples (non-nested PCR positives); Spots 13-21: P. vannamei samples (nested PCR positives)

positive DNA dot-blot hybridisation reactions confirmed that the positive amplification of WSSV gene in PCR is from shrimp genuinely infected with virus and ruled out the chances of amplification of DNA from mechanically present viruses or other contaminants.

IHHNV infection results in bent or deformed rostrums, wrinkled walking legs, cuticular roughness and other cuticular deformities leading to stunted growth in P. vannamei (Kalagayan et al., 1991). Earlier researchers have reported the low $(32 \%)$ and high $(66 \%)$ prevalence of IHHNV infection of cultured $P$. vannamei samples in Indian farms (Moger et al., 2011; Otta et al., 2014). In the present study, IHHNV was detected in four shrimp samples out of 81 samples screened, giving an overall occurrence of $4.9 \%$. This virus was detected in samples only by nested PCR, yielding a product size of 309 bp (Fig. 4), indicating lower load of the virus. Though runt deformity syndrome is the most typical sign of IHHNV infection, the infected shrimps in this study were devoid of such symptoms. This could be due to lack of optimal

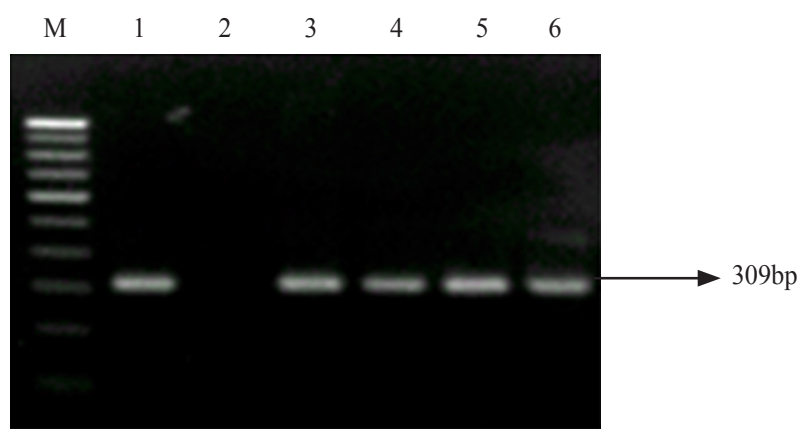

Fig. 4. Nested PCR detection of IHHNV in P. vannamei

(1) M: 100 bp DNA ladder; (2) Lane 1: Nested PCR amplification of positive control; (3) Lane 2: Nested PCR amplification of negative control; (4) Lane 3 to 6: Nested PCR amplification of DNA extracted from $P$. vannamei viral concentration to cause the disease or due to chronic nature of the infection as reported by Bell and Lightner (1984) and Primavera and Quinitio (2000). The absence of clinical signs in our study could be attributed to the collection of samples during the early part of culture operation (40 days of culture). Other DNA viruses such as MBV, HPV and RNA were not detected in any of the samples during the present study.

The present study provides information regarding the prevalence of infectious viruses of $P$. vannamei cultured in Karnataka, India. P. vannamei was introduced to India as a hardy and disease-resistant species. Further, SPF broodstocks are being used by hatcheries in India to produce $P$. Vannamei post-larvae. In spite of this, cultured shrimp are found infected by the existing virulent viruses. Our results indicate that WSSV is highly prevalent in Indian aquaculture environment and $P$. vannamei is highly susceptible to WSSV in Indian culture conditions. The present study strongly emphasises the need to follow the best management practices (BMP), including strict biosecurity measures to get rid of viral pathogens in farms for the sustainable aquaculture of $P$. vannamei in India.

\section{Acknowledgements}

The research was funded by National Fisheries Development Board (NFDB), Hyderabad, India under the project National Surveillance Programme for Aquatic Animal Diseases (NSPAAD). The authors acknowledge the DBT-Bioinformatics Centre, College of Fisheries (Karnataka Veterinary, Animal and Fisheries Sceinces University), Mangalore.

\section{References}

Afsharnasab, M., Mortezaei, R., Yegane, V. and Kazemi, B. 2009. Gross sign, histopathology and polymerase chain reaction observations of white spot syndrome virus in specific pathogen free shrimp Litopenaeus vannamei in Iran. Asian J. Anim. Vet. Adv., 4(6): 297-305. doi: 10.3923/ ajava.2009.297.305.

Ananda Raja, R., Panigrahi, A. and Sujeet Kumar 2012a Epidemiological investigation of brackishwater culture system of West Bengal. J. Appl. Aquacult., 24: 1, 49-59. DOI: $10.1080 / 10454438.2012 .652029$.

Ananda Raja, R., Sujeet Kumar, Sundaray, J. K., De, D., Biswas, G. and Ghoshal, T. K. 2012b. Hematological parameters in relation to sex, morphometric characters and incidence of white spot syndrome virus in tiger shrimp Penaeus monodon Fabricius, 1798 from Sunderban, West Bengal. Indian J. Fish., 59(4): 169-174.

Balakrishnan, G., Peyail, S., Kumaran, R., Theivasigamani, A., Kotiya, A. S., Solanki, J. B. and Srinivasan, N. 2011. First report on white spot syndrome virus (WSSV) infection in white leg shrimp Litopenaeus vannamei (Crustacea, 
Penaeidae) under semi-intensive culture condition in India. AACL Bioflux, 4(3): 301-305

Belcher, C. R. and Young, C. R. 1998. Colourimetric PCRbased detection of monodon baculovirus in whole Penaeus monodon postlarvae. J. Virol. Methods, 74: 21-29. doi:10.1016/S0166-0934(98)00067-6.

Bell, T. A. and Lightner, D. V. 1984. IHHN virus: infectivity and pathogenicity studies in Penaeus vannamei. Aquaculture, 38(3): 185-194. doi: 10.1016/0044-8486(84)90142-X.

Bondad-Reantaso, M. G., Subasinghe, R. P., Arthur, J. R., Ogawa, K., Chinabut, S., Adlard, R., Tan, Z. and Shariff, M. 2005. Disease and health management in Asian aquaculture. Vet. Parasitol., 132: 249-272. doi: 10.1016/j. vetpar.2005.07.005.

Briggs, M., Funge-Smith, S., Subasinghe, R. and Phillips, M. 2004. Introductions and movement of Penaeus vannamei and Penaeus stylirostris in Asia and the Pacific. RAP Publication 2004/10. FAO Regional Office for Asia and the Pacific, Bankok, p. 1-12.

Browdy, C. L., Holloway, Jr. J. D., King, C. O., Stokes, A. D., Hopkins, J. S. and Sandifer, P. A. 1993. IHHN virus and intensive culture of Penaeus vannamei: effects of stocking density and water exchange rates. J. Crustacean Biol., 13(1): 87-94. doi: 10.2307/1549124.

Calderon, J. V., Bayot, B., Betancourt, I. and de Graindorge, A. V. 1999. Monitoreo del virus de la mancha blanca en Ecuador. El Mundo Acuicola, 5: 211-214.

Cavalli, L. S., Marins, L. F., Netto, S. and Abreu, P. C. 2008. Evaluation of white spot syndrome virus (WSSV) in wild shrimp after a major outbreak in shrimp farms at Laguna, Southern Brazil. Atlantica Rio Grande, 30(1): 45-52.

Cheng, L., Lin, W. H., Wang, P. C., Tsai, M. A., Hsu, J. P. and Chen, S. C. 2013. White spot syndrome virus epizootic in cultured Pacific white shrimp Litopenaeus vannamei (Boone) in Taiwan. J. Fish Dis., 36(12): 977-985. doi: 10.1111/jfd.12027.

Dos Santos-Braz, R. F., Rodrigues de Oliveira da Silva, C. P., Garcia-Reis, L., Cunha-Martins, P. C., Pereira de Sales, M. and Vasconcelos-Meissner, R. 2009. Prevalence of infectious hypodermal and hematopoietic necro-sis virus (IHHNV) in Penaeus vannamei cultured in northeastern Brazil. Aquaculture, 288: 143-146. doi: 10.1016/j. aquaculture.2008.11.021.

Ferasyi, T. R., Zulpikar, Z., Sugito, S., Muchlisin, Z. A., Razali, R., Nurliana, N. and Azhar, A. 2015. A preliminary study of white spot syndrome virus (WSSV) infection on vannamei shrimp (Litopenaeus vannamei) cultured in semiintensive ponds in Bireuen District of Aceh Province, Indonesia. AACL Bioflux, 8(5): 810-816.

Flegel, T. W. 2006a. Detection of major penaeid shrimp viruses in Asia, a historical perspective with emphasis on Thailand. Aquaculture, 258: 1-33. doi: 10.1016/j. aquaculture.2006.05.013.
Flegel, T. W. 2006b. The special danger of viral pathogens in shrimp translocated for aquaculture. Science Asia, 32:215-221. doi: 10.2306/scienceasia 1513-1874.2006.32.215.

Flegel, T. W., Nielsen, L., Thamavit, V., Kongtim, S. and Pasharawipas, T. 2004. Presence of multiple viruses in non-diseased, cultivated shrimp at harvest. Aquaculture, 240: 55-68. doi:10.1016/j.aquaculture.2004.06.032.

Hossain, S., Chakraborty, A., Joseph, B., Otta, S. K., Karunasagar, I. and Karunasagar, I. 2001. Detection of new hosts for white spot syndrome virus of shrimp using nested polymerase chain reaction. Aquaculture, 198: 1-11. doi.org/10.1016/S0044-8486(00)00571-8.

Kalagayan, G., Godin, D., Kanna, R., Hagino, G., Sweeney, J., Wyban, J. and Brock, J. 1991. IHHN virus as an etiological factor in runt-deformity syndrome of juvenile Penaeus vannamei cultured in Hawaii. J. World Aquacult. Soc., 22(4): 235-243. doi: 10.1111/j.1749-7345.1991.tb00740.x.

Lightner, D. V. 1999. The penaeid shrimp viruses TSV, IHHNV, WSSV and YHV: current status in the Americas, available diagnostic methods and management strategies. J. Appl. Aquac., 9(2): 27-52. doi: org/10.1300/J028v09n02_03.

Mijangos-Alquisires, Z., Quintero-Arredondo, N., CastroLongoria1, R., Grijalva-Chon, J. M. and Ramos-Paredes, J. 2006. White spot syndrome virus (WSSV) in Litopenaeus vannamei captured from the Gulf of California near an area of extensive aquaculture activity. Dis. Aquat. Org., 71(1) 87-90. doi: 10.3354/dao071087.

Moger, R., Mohan, S. A., Venugopal, M. N. and Karunasagar, I. 2011. Presence of multiple viruses in newly introduced white leg shrimp, Penaeus vannamei and assessment of their risk to aquaculture in India. In: Abstracts of the Eighth Symposium on Diseases in Asian Aquaculture, 2125 November, 2011, Mangalore, India, 2011, 158 pp.

Motte, E., Yugcha, E., Luzardo, J., Castro, F., Leclercq, G., Rodriiguez, J., Paul, M., Oswaldo, B., Javier, S., Manuel, T., Karina, M., Alexandra, N., Narda, T., Virna, C., Eric, M. and Viviane, B. 2002. Prevention of IHHNV vertical transmission in the white shrimp, Litopenaeus vannamei. Aquaculture, 219: 57-70. doi: 10.1016/S0044-8486(02)00631-2.

MPEDA 2016. MPEDA database. http://164.100.150.120/ mpeda/cms.php?id. (Accessed $1^{\text {st }}$ August 2016).

Nunan, L. M., Poulos, B. T. and Lightner, D. V. 1998. Reverse transcription polymerase chain reaction (RT-PCR) used for the detection of taura syndrome virus (TSV) in experimentally infected shrimp. Dis. Aquat. Org., 34: 87-91. doi: 10.3354/dao034087

OIE 2010. Diseases listed by the OIE. Aquatic animal health code. World Organisation for Animal Health, Paris.

Otta, S. K., Karunasagar, I. and Karunasagar, I. 2003. Detection of monodon baculovirus and white spot syndrome virus in apparently healthy Penaeus monodon post-larvae from India by polymerase chain reaction. Aquaculture, 220: 59-67. doi:10.1016/S0044-8486(02)00340-X. 
Otta, S. K., Arulraj, R., Praveena, P. E., Manivel, R., Panigrahi, A., Bhuvaneswari, T., Ravichandran, P., Jithendran, K. P. and Ponniah, A. G. 2014. Association of dual viral infection with mortality of Pacific white shrimp (Litopenaeus vannamei) in culture ponds in India. Virus Disease, 25(1): 63-68. doi: 10.1007/s13337-013-0180-x.

Pazir, M. K., Afsharnasab, M., Jalali, J. B., Sharifpour I., Motalebi, A. A. and Dashtiannasab, A. 2011. Detection and identification of white spot syndrome virus (WSSV) and infectious hypodermal and hematopoietic necrosis virus (IHHNV) of Litopenaus vannamei from Bushehr and Sistan and Baloochestan provinces, Iran, during 2009-2010. Iran. J. Fish. Sci., 10(4): 708-726.

Phalitakul, S., Janenuj, W., Meena, S. and Nareera, T. V. 2006. The molecular detection of taura syndrome virus emerging with WSSV in penaeid shrimps of Thailand. Aquaculture, 260: 77-85. doi:10.1016/j.aquaculture.2006.05.040.

Phromjai, J., Boonsaeng, V., Withyachumnarnkul, B. and Flegel, T. W. 2002. Detection of hepatopancreatic parvovirus in Thai shrimp Penaeus monodon by in situ hybridisation, dot blot hybridisation and PCR amplification. Dis. Aquat. Org., 51: 227-232. doi: 10.3354/dao051227.

Poulos, B. T. and Lightner, D. V. 2006. Detection of infectious myonecrosis virus (IMNV) of penaeid shrimp by reversetranscriptase polymerase chain reaction (RT-PCR). Dis. Aquat. Org., 73: 69-72. doi: 10.3354/dao073069.

Primavera, J. H. and Quinitio, E. T. 2000. Runt-deformity syndrome in cultured giant tiger prawn Penaeus monodon. J. Crustac. Biol., 20(4): 796-802. doi: 10.1651/0278-0372 (2000)020[0796:RDSICG]2.0.CO;2.

Rai, P., Pradeep, B., Karunasagar, I. and Karunasagar, I. 2009. Detection of viruses in Penaeus monodon from India showing signs of slow growth syndrome. Aquaculture, 289(3): 231-235. doi:10.1016/j.aquaculture.2008.12.035.

Remany, M. C., Cyriac, D., Nagaraj, S., Babu R., Panda, A. K., Kumar. J. and Thampi Samraj, Y. C. 2010. Specific pathogenfree assurance of imported Pacific white shrimp Litopenaeus vannamei (Boone, 1931) in the Aquatic Quarantine Facility, Chennai. Curr. Sci., 99(12): 1656-1658.

Rodriguez, J., Bayot, B., Amano, Y., Panchana, F., de Blas, I., Alday, V. and Calderon, J. 2003. White spot syndrome virus infection in cultured Penaeus vannamei
(Boone) in Ecuador with emphasis on histopathology and ultrastructure. J. Fish Dis., 26(8): 439-450. doi: 10.1046/j.1365-2761.2003.00483.x.

Sanathkumar, H., Ravi, C., Padinhatupurayil, S. B., Mol, M., Prasad, J. K. and Nayak, B. B. 2014. Microbiological investigation of persistent mortalities in Litopenaeus vannamei grown in low saline waters in India. J. Aquat. Anim. Health, 26(3): 154-159. doi: 10.1080/08997659.20 14.902875 .

Senanan, W., Panutrakul, S., Barnette, P., Chavanich, S., Mantachitr, V., Tangkrock-Olan, N. and Viyakarn, V. 2009. Preliminary risk assessment of Pacific white leg shrimp ( $P$. vannamei) introduced to Thailand for aquaculture. Aquac.. Asia, 14(4): 28-31.

Tang, K. F. J., Navarro, S. A. and Lightner, D. V. 2007. PCR assay for discriminating between infectious hypodermal and hematopoietic necrosis virus (IHHNV) and virus-related sequences in the genome of Penaeus monodon. Dis. Aquat. Org., 74: 165-170. doi: 10.3354/ dao074165.

Tsai, M. F., Kou, G. H., Liu, H. C., Liu, K. F., Chang, C. F., Peng, S. E., Hsu, H. C., Wang, C. H. and Lo, C. F. 1999. Long term presence of white spot syndrome virus (WSSV) in a cultivated shrimp population without disease outbreaks. Dis. Aquat. Org., 38: 107-114. doi:10.3354/dao038107.

Tu, C., Huang, H. T., Chuang, S. H., Hsu, J. P., Kuo, S. T., Li, N. J., Hsu, T. L., Li, M. C. and Lin, S. Y. 1999. Taura syndrome in Pacific white shrimp Penaeus vannamei cultured in Taiwan. Dis. Aquat. Org., 38: 159-161.

Umesha, K. R., Bob Kennady, M. D., Manjanaik, B., Venugopal, M. N., Karunasagar, I. and Karunasagar, I. 2006. High prevalence of dual and triple viral infection in black tiger shrimp ponds in India. Aquaculture, 258: 91-96. doi:10.1016/j.aquaculture.2006.04.003.

Walker, P. J. and Winton, J. R. 2010. Emerging viral diseases of fish and shrimp. Vet. Res., 41: 51-75. doi: 10.1051/ vetres/2010022.

Wayban, J., Walsh, W. A. and Godin, D. M. 1995. Temperature effects on growth, feeding rate and feed conversion of the Pacific white shrimp (Penaeus vannamei). Aquaculture, 135: 267-279. doi:10.1016/0044-8486(95)00032-1. 